\title{
Peran Guru Agama Dalam Menanamkan Moderasi Beragama Samsul AR
}

Sekolah Tinggi Ilmu Bahasa Arab (STIBA) Darul Ulum Banyuanyar Pamekasan samsular999@gmail.com

\begin{abstract}
Abstrak
Islam encourages the followers to be moderate, belances, not extreme, and not inclusive. TheTawasuthis part of the moderation of religion that must be embeded to the students so that students have a moderate attitude in thier life of the nation and state. In the middle of the advancement of the Indonesian nation, religious moderation is needed by all human being and its must be taught to students so that they can become peaceful, compassionate and tolerance people in the future. The involvement of religious teachers in providing understanding of the tawasuth for the students are needed in order that its can be habatuation in their life. The content of Islamic religious education is emphasized on the understanding of compassion, mutual love, mutual respect, and help each other in kindness. Because with this understanding, the students can implement it in their daily life. This paper explains the role of religious teacher in embeding religious moderation. This paper uses the library research method with a descriptive analysis approach.
\end{abstract}

Key Word: Moderation, Islamic, and Religious Teacher.

Islam menganjurkan pengikutnya bersifat tawasuth, bermakna ditengah-tengah atau seimbang, tidak ekstrim, dan tidak inklusif. Sifat tawasuth ini bagian dari moderasi beragama yang harus ditanamkan kepada peserta didik agar peserta didik memiliki sikap moderat dalam kehidupan berbangsa dan bernegara. Ditengah kemajmukan bangsa Indonesia, moderasi beragama mutlak diperlukan dan diajarkan kepada peserta didik agar menjadi manusia yang mendamaikan, penuh kasih sayang dan toleran dimasa yang akan datang. Keterlibatan guru agama dalam memberikan pemahaman tentang sifat tawasuth bagi peserta didik perlu dibudidayakan dan gaungkan. Konten materi pendidikan agama islam ditekankan pada pemahaman tentang kasih sayang, saling mencintai, saling menghormati, dan tolong menolong dalam kebaikan. Karena dengan pahaman tersebut, peserta didik dapat mengimplentasikan dalam kehidupan sehari-hari peserta didik.Tulisan membahasan tentang peran guru agama dalam menanamkan moderasi beragama. Tulisan ini menggunakan metode library research dengan pendekatan analisis diskritif.

Key Worda: Moderasi, Islam, dan Guru. 


\section{Pendahuluan}

Konflik berkepanjangan atas nama agama sering kali terjadi di berbagai daerah di Indonesia. Masjid dibakar, Geraja diserang, tokoh agama menjadi sasaran kekejaman tangan-tangan tidak bertanggung jawab, bom bunuh diri mengatasnamakan agama, radikalisme dan vandalism dan diskriminasi atas nama isu sara seringkali terjadi dan menjadi pemberitaan nasional.

Tentunya, insiden kekerasan atas nama agama suku, ras dan budaya tidak bisa dielakkan karena bangsa Indonesia terdiri dari berbagai macam suku, agama, dan budaya yang beraneka ragam. Percikan kebencian, kekerasan, dan vandalism pasti terjadi karena ketersinggungan antar golongan. Jika tidak dikelola dengan baik, maka akan menjadi boom waktu yang sekali-kali dapat meledak dan menghancurkan tatanan masyarakat Indonesia yang sudah mapan.

Lihat saja beberapa insident yang mencoreng nama baik bangsa yang menjujung tinggi nilai-nilai persatuan dan toleransi. Dilatar belakangi dengan adanya insiden tolikara (Papua) pada saat perayaan idul-fitri 1436 H., pembakaran Gereja di Aceh Singkil, pengeboman yang terjadi di Paris Prancis yang menewaskan lebih dari seratus orang yang tidak berdosa. ${ }^{1}$ Bom bunuh diri di Surabaya merupakan bukti bahwa ketersinggungan antar suka, ras, budaya, khususnya agama mudah terjadi. Kekerasan atas nama agama seakan memberikan kesan bahwa agama telah menghalalkan untuk membunuh manusia, membakar masjid dan gereja, menggangu orang yang sedang merayakan hari raya dan lain sebagainya. Padahal agama mengajarkan semua pengikutnya untuk saling menyangi, menghargai, dan menghormati orang lain. ${ }^{2}$

Telah diketahui bersama bangsa Indonesia merupakan bangsa majmuk yang terdiri dari berbagai macam pulau, ras, etnis, bahasa, dan suku yang kurang lebih sekitar 600 suku dengan berbagai macam budaya yang berbedabeda. ${ }^{3}$ Dengan adanya berbagai macam suku, bangsa, dan budaya tersebut tidak heran jika Indonesia disebut sebagai salah satu Negara multikulral terbesar di dunia. ${ }^{4}$

Setiap agama pasti memiliki aturan terkait dengan toleransi. Islam sebagai agama terbesar yang dianut oleh mayoritas warga Indonesia tentunya memiliki

\footnotetext{
${ }^{1}$ Tribujogja, senin, 16 November 2015, hlm, 1.

${ }^{2}$ Lihat Nurkholis Majid, Pluralitas Agama: Kerukunan dalam Kergaman, (Jakarta: Kompas Nusantra, 2001), hlm. 38-39.

${ }^{3}$ H.A.R. Tilaar, Multikulturalisme tantangan Global Masa Depan dalam Transformasi Pendidikan Nasional, (Jakarta: Grasindo, 2003), hlm. 114.

${ }^{4}$ Ainul Yakin, Pendidikan Multikultural; Cross-Culture Understanding untuk Demokrasi dan Keadilan, (Yogyakarta: Pilar Media, 2005), hlm. 3.
} 
aturan-aturan yang mengacu kepada kemaslahatan umat islam. Setidaknya, aturan-aturan itu memiliki korelasi dengan misi moderasi beragama yang menjadi landasan Negara Indonesia. Islam sendiri dalam pembentukan hukumnya memiliki lima prinsip yaitu menjaga agama (hifdzal-din), menjaga jiwa (hifdzal-nafs), menjaga akal (hifdzal-'ql) menjaga keturunan (hifdzal-nasl), dan menjaga harta(hifdzal-mal). ${ }^{5}$ Dari prinsip hukum islam tersebut dapat digambarkan bahwa hak untuk hidup bersama, menghargai keberadaan orang lain, menjaga keberlangsungan hidup dan menjaga nyawa seseorang harus dijunjung tinggi.

Insident kekerasan mengatasnamakan agama telah bertentangan dengan prinsip kehidupan umat manusia. Insiden-insiden kekerasan tersebut terjadi disebabkan karena pemahaman agama yang persial, konflik pendirian tempat ibadah, dan ketidak siapan hidup berdampingan merupakan salah satu faktor penyebat terjadinya intoleran. ${ }^{6}$ Pemahaman yang persial itu akan membuat pengikutnya bertindak tidak sesuai dengan ajaran agama.

Maka dibutuhkan pemahaman yang komprehensif yang dapat mengakomodir dan meluruskan paham-paham yang bertentangan dengan kemaslahatan bersama terlebih untuk keberlangsungan kehidupan umat beragama. Penanganan secara khusus dan terencana harus dilakukan oleh berbagai pihak agar dapat menyelesaikan konflik kekerasan atas nama agama. Karena apabila tidak ditangani secara serius, kerugian ekonomi, social, politik dan materi yang luar biasa7akan dialami oleh bangsa Indonesia.

Lembaga pendidikan memiliki peran strategis untuk memutus mata rantai kekerasan atas nama agama. Pendekatan edukatif bagi selaruh peserta didik yang dapat diimplementasikan dalam pendidikan damai yang diintegrasikan dengan kurikulum sekolah, latihan penyelesaikan konflik secara konstruktif, mediasi dan negosiasi oleh teman sebaya ${ }^{8}$ merupakam usaha bersama agar bangsa Indonesia menjadi bangsa yang mendamaikan. Pengetahuan keagamaan yang luas dan tidak parsial harus diajarkan dilembaga pendidikan agar peserta didik memiliki pondasi paham keagamaan yang tidak sempit.

Oleh sebaba itu, diperlukan peran guru agama dalam menanamkan moderasi beragama dalam kehidupan berbangsa dan bernegara yang multikultural ini. Moderasi beragama sebagaimana digambarkan oleh Fahruddin dalam Akhmadi, memiliki makna seimbang, ditengah-tengah, tidak hlm. 12

\footnotetext{
${ }^{5}$ Edi, Ah.Iyubenu, Hate Speech' dalam Kecamata Islam, Kedaulatan Rakyat, 13 November 2015,
}

\footnotetext{
${ }^{6}$ Biyanto, Urgensi Plurarisme, Kedaulatan Rakyat, 13 November 2015, hlm. 12.

7 Akhmadi, Agus. "Moderasi Beragama Dalam Keragaman Indonesia." Inovasi 13.2 (2019): 46.

${ }^{8}$ Akhmadi, Agus. "Moderasi ......Hlm, 46.
} 
berlebihan, tidak truth clime, tidak menggunakan legitimasi teologi yang ekstrim, mengaku kelompok dirinya paling benar, netral, dan tidak berafiliasi dengan partai politik tertentu. ${ }^{9}$

Dengan demikian, moderasi beragama sangat perlu untuk ditanamkan kepada siswa agar tercipta hubungan harmonis antara guru, peserta didik, masyarakat dan lingkungan sekitar sehingga tercipta lingkangan yang damai dan aman dari berbagai ancaman. Bagaimana peran guru agama dalam menanamkan moderasi beragama? Bagaimana implementasi moderasi beragama dalam prosesbelajar mengajar?

\section{Moderasi Beragama Bangsa Indonesia}

Bangsa Indonesia merupakan bangsa yang majmuk, multibudaya, multietnis, dan multi agama.Jika tidak dikelola dengan sebaik mungkin, maka perpecahan akan tumbuh dan melanda negeri kita Indonesia. Maka sudah seharusnya bagi seluruh rakyat Indonesia untuk terus menjaga dan merawat kemajmukan dengan seluruh kekuatan jiwa dan raga, harus terus dijaga dan dirawat sepanjang hayat. Tidak boleh ada gesekan sekecil apapun baik dari gesekan agama, perbedaan, perselisihan dan perdebatan karena hal ini akan menghancurkan persatuan dan kesatuan bangsa dan menjadi kerugian besar bagi bangsa Indonesia. Sebagaimana disampaikan oleh KH. Hasyim Asy'ary pada tahun 1937, Muktamar NU ke 12 di Malang bahwa perdebatan, perselisihan, saling menghina, menjatuhkan, bermusuhan merupakan musibah dan menjadi kerugian sangat besar bagi bangsa Indonesia. ${ }^{10}$ Lebih lanjut $\mathrm{KH}$. Asya'ari melanjutkan bahwa bangsa Indonesia merupakan bangsa yang satu, agama satu, Islam, mazhab satu, serumpun, dan ahlus sunnah wal jamaah. ${ }^{11}$ Jika demikian mengapa masih mau berpecah belah? Maka paham moderasi beragama yang ditanamkan oleh KH. Hasyim Asy'ari ini perlu digaungkan kembali oleh Guru Agama di bangsa Indonesia ini.

Moderasi dalam bahasa arab dikenal dengan kata wasath atau wasathiyah, sepadan dengan kata tawassuth yang memiliki makna ditengah-tengah, I'tidal (adil), tawazun (berimbang). Dalam Bahasa Latin Moderasi adalah moderâtio yang bermakna ke-sedang-an yaitu tidak berlebihan tidak kekurangan, atau juga bermakna penguasaan didiri. ${ }^{12}$ Moderasi beragama sebagaimana dirumuskan oleh TIM Kementrian Agama RI memiliki makna kemajemukan

\footnotetext{
${ }^{9}$ Akhmadi, Agus. "Moderasi ...... hlm, 51.

${ }^{10}$ Muhammad Sulton Fatoni, Buku Pintar Islam Nusantra, (Tanggeran Selatan, IIMaN: 2017), Hlm. 111

${ }^{11}$ Muhammad Sulton Fatoni, Buku Pintar......Hlm. 111

${ }^{12}$ Kementerian Agama, R. I. "Moderasi Beragama." Jakarta: Badan Litbang dan Diklat Kemenag RI (2019), Hlm. 15-17.
} 
dan mutlak diperlukan dalam diberbagai kondisi bangsa Indonesia yang majmuk dengan cara pemberian pengajaran agama yang komprehensif yang dapat mewakili setiap orang yang ada melalui ajaran yang luwes dengan tidak meninggalkan teks (Al-Qur'an dan Hadist), serta pentingnya penggunaan akal adalah sebagai solusi dari setiap masalah yang ada. ${ }^{13}$

Lebih lanjut, Tarmizi Tohor mengungkapkan dengan mengutip pendapatnya Lukman Hakim Syaifuddin bahwa seorang menjadi moderat bukan berarti meninggalkan agama sendiri, menjadi moderat bukan berarti menjadi lemah dalam beragama, menjadi moderat bukan berarti cenderung terbuka dan mengarah kepada kebebasan, tetapi menjadi moderat berarti sebuah jalan tengah dalam keberagaman agama di Indonesia. Ia adalah warisan budaya Nusantara yang berjalan seiring, dan tidak saling menegasikan antara agama dan kearifan lokal (local wisdom). ${ }^{14}$

Moderasi beragama bagi bangsa Indonesia muklak diperlukan karena disadari atau tidak bangsa Indonesia merupakan bangsa yang beragam. Keberagaman bangsa Indonesia bukan hasil karya manusia tetapi merupakan takdir yang diwariskan oleh Tuhan terhadap bangsa Indonesia. Hal ini dapat dilihat dari jumlah suku besar sebanyak 633 dan jumlah bahasa daerah sebanyak 652 dan dan sekitar 18.306 ribu pulau. Keragama bangsa Indonesia bukan untuk ditawar tetapi untuk diterima dan dijaga agar tercipta persatuan dan kesatuan bangsa Indonesia yang damai. ${ }^{15}$

Dalam al-Qur'an kata moderasi tersurat dalam surat al-Baqarah ayat 143 yang berbunyi

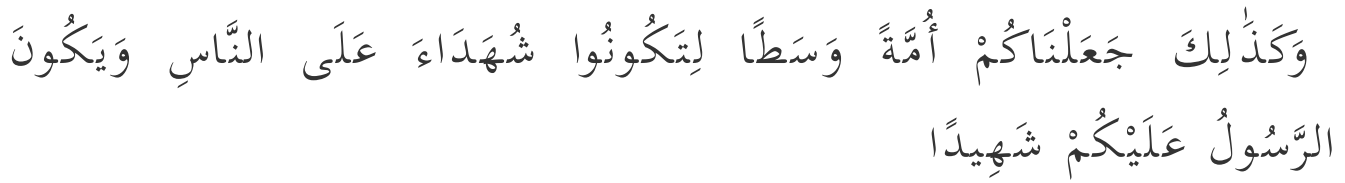

"Dan demikian pula kami menjadikan kamu umat Islam, umat pertengahan (adil dan terpilih), agar kamu menjadi saksi atas seluruh manusia dan agar Rasul (Muhammad) menjadi saksi atas kamu" (Q.S. Al-Baqarah: 143)

Ayat tersebut memberikan isyarat bagi seluruh umat manusia agar berlaku adil dan terpilih, moderat atau berada ditengah-tengah dalam segi akidah, ibadah, dan muamalah. ${ }^{16}$ Bersikap moderat berarti tidak fanatik apalagi sampai pada taraf fanatime buta lebih-lebih sampai mengkafirkan orang lain.

\footnotetext{
${ }^{13}$ Fauzi, Ahmad. "Moderasi Islam, Untuk Peradaban Dan Kemanusiaan." Jurnal Islam Nusantara 2.2 (2018), hlm, 233.

${ }^{14}$ Tarmidzi Tohor, https://bimasislam.kemenag.go.id/post/opini/pentingnya-moderasi-beragama diakses pada 25-01-20

${ }^{15}$ Kementerian Agama, R. I. "Moderasi Beragama." Jakarta: Badan Litbang dan Diklat KemenagRI (2019), Hlm. 2-3

${ }^{16}$ https://tafsirweb.com/598-surat-al-baqarah-ayat-143.html diakses pada 25-01-2020.
} 
Karena sikap fanatisme buta ini dapat menyebabkan konflik keagamaan yang dapat menyebabkan perpecahan bagi bangsa Indonesia. Moderasi beragama merupakan salah satu strategi kebudayaan dalam merawat keindonesiaan. ${ }^{17}$

\section{Peran Guru Agama dalam Menanamkan Moderasi beragama}

Pendidikan merupakan hal yang sangat penting bagi seluruh warga Indonesia. Setiap warga negara Indonesia memiliki hak untuk mengenyam pendidikan sembilan tahun. Sebagaimana diatur dalam undang-undang nomer 2 tahun 1989 yang menyebutkan bahwa pemerintah berupaya meningkatkan taraf kehidupan rakyat dengan mewajibkan semua warga negara Indonesia yang berusia 7- 12 tahun dan 12-15 tahun untuk menamatkan pendidikan dasar dengan program 6 tahun di SD dan 3 tahun di SLTP secara merata. ${ }^{18}$

Begitu juga dengan prinsip-prinsip penyelenggaraan pendidikan secara jelas juga telah diuraikan dalam Undang-Undang Sisdiknas 20 tahun 2003, yaitu tercantum pada pasal 4, bahwa : 1) Pendidikan diselenggarakan secara demokratis dan berkeadilan serta tidak diskriminatif dengan menjunjung tinggi hak asasi manusia, nilai keagamaan, nilai kultural, dan kemajemukan bangsa, 2) Pendidikan diselenggarakan sebagai satu kesatuan yang sistemik dengan system terbuka dan multimakna, 3) Pendidikan diselenggarakan sebagai suatu proses pembudayaan dan pemberdayaan peserta didik yang berlangsung sepanjang hayat, 4) Pendidikan diselenggarakan dengan memberi keteladanan, membangun kemauan, dan mengembangkan kreativitas peserta didik dalam proses pembelajaran, 5) Pendidikan diselenggarakan dengan mengembangkan budaya membaca, menulis, dan berhitung bagi segenap warga masyarakat, 6) Pendidikan diselenggarakan dengan memberdayakan semua komponen masyarakat melalui peran serta dalam penyelenggaraan dan pengendalian mutu layanan pendidikan. ${ }^{19}$

Tujuan pendidikan nasional adalah untuk mencerdaskan kehidupan bangsa. Mencerdaskan berarti membuat peserta didik mengenali diri sendiri, mengenali potensi diri, lingkungan, dan masyarakat sekitar. Guru harus mampu memberikan pencerahan tentang moderasi beragama agar peserta didik menjadi manusia yang mendamaikan baik di lingkungan maupun alam sekitar. Dengan pengetahuan tersebut diharapkan tercipta kerukunan hidup antar sesama (live together) dan bisa hidup berdampingan (live with other ) dengan orang lain yang berbeda agama, keyakinan, ras etnis, dan lain

\footnotetext{
${ }^{17}$ Kementerian Agama, R. I. "Moderasi Beragama." Hlm. 10.

${ }^{18}$ Undang-undang Pemerintah nomor 2 tahun 1989.

${ }^{19}$ UU Republik Indonesia Nomor 20 Tahun 2003 tentang Sistem Pendidikan Nasiona, (Jakarta, Lembaran Negara, 8 Juli 2003).
} 
sebagainya. ${ }^{20}$ Tentunya peran guru mutlak diperlukan. Dalam hal ini guru harus memiliki prinsip keguruan yang dapat memperlakukan peserta didik dengan baik sehingga tercapai tujuan pendidikan.

Adapun prinsip-prinsip keguruan dapat dijelaskan sebagai berikut:

a) Seorang guru harus dapat membangkitkan peserta didik pada materi pelajaran yang diberikan serta dapat menggunakan media dan sumber belajar yang berveriasi.

b) Guru harus memampu membangkitkan minat peserta didik untuk aktif dalam berfikir serta mencari dan menemukan sendiri pengetahuannya.

c) Guru mampu membuat urutan (sequence) dalam pemberian mata pelajaran dan penyesuaian dengan usia dan tahapan perkembangan peserta didik.

d) Guru mampu mengembangkan pelajaran yang akan diberikan dengan pengetahuan yang dimiliki peserta didik agar peserta didik menjadi mudah dalam memahami pelajaran yang diberikan

e) Guru mampu menjelaskan materi secara berulang-ulang dengan harapan peserta didik lembih memahami materi yang telah diberikan

f) Guru wajib memperhatikan dan memikirkan korelasi atau hubungan antar mata pelajaran atau praktik nyata dalam kehidupan sehari-hari.

g) Guru harus tetap menjaga konsentrasi peserta didik dengan cara memberikan kesempatan berupa pengalaman secara langsung, mengamati, meneliti, dan menyimpulkan pengetahuan yang didapatnya.

h) Guru harus mengembangkan peserta didik dalam membina hubungan sosial, baik dalam kelas maupun luar kelas.

i) Guru harus menyelidiki dan mendalami perbedaan peserta didik secara individu agar dapat melayani peserta didik sesuai perbedaan. ${ }^{21}$

Sebagai seorang guru tidak hanya bertugas memberikan pengetahuan kepada peserta didik tetapi juga dapat membentuk karakter menjadi pribadi yang unggul mandiri dan dapat mengamalkan ilmu pengetahuannya. Jika flash back pada sejarah peradaban islam, sebagaimana digambarkan oleh Mujamil Qomar (2012) bahwa islam tidak hanya mengajarkan ilmu pengetahuan untuk mewujudkan prestasi akademik yang gemilang (science for science), tetapi untuk mewujudkan kedamaian dan perdamaian umat manusia (science for peace of society). Dengan katalain bahwa adanya ilmu pengetahuan untuk kesejahteraan

${ }^{20}$ Zakiyuddin Baidhawy, Pendidikan Agama Berwawasan Multikultural, (Jakarta: Earlangga, 2005), hlm. 79.

${ }^{21}$ Hamzah B. Uno, Profesi Kependidikan, Problema, Solusi, dan Reformasi Pendidikan di Indonesia (Jakarta: Bumi Aksara, 2007) hlm 16. 
umat manusia (science for human welfare) sehingga arah kemajuan sains maupun teknologi (peradaban) bisa dikendalikan dengan tetap berada dalam jalan yang lurus al-sirath al-mustaqim. ${ }^{22}$ Sebuah peradaban umat manusia yang sejahtera, hidup damai dalam perbedaan dengan konsep pembelajaran sepenjang hayat yaitu learning to know (belajar untuk mengetahui), learning to do (belajar untuk mengerjakan atau implementasikan dalam kehidupan), learning to live together (belajar hidup berdampingan dengan orang lain segaama, sebangsa, dan setanah air), dan unity in diversity (bersatu dalam perbedaan budaya, keyanikanan, dan agama) atau dengan meminjam bahasa Mukti Ali (agree in disagreement) setuju dalam ketidak setujuan karena sesunggunya bangsa Indonesia merupakan bangsa yang bersatu.

Guru sebagai manusia paripurna dimana segala tindakan, perbuatan, sikap, dan perkataan terakam dalam kehidupan peserta didik harus mampu menjadi suri tauladan yang baik bagi peserta didik terlebih dalam kehidupan berbangsa dan bernegara. Guru memiliki peran sentral dalam mengolah perbadaan dalam beragama karena guru merupakan role model bagi peserta didik. Hal ini sebagaimana pendapatknya Luc Reychler (2006) dalam teorinya Arsitektur perdamaian menyebutkan, dalam pengelolaan perbedaan agama dibutuhkan sejumlah syarat Pertama, adanya saluran komunikasi yang efektif dan harmoni sehingga memungkinkan terjadi proses diskusi, klarifikasi, dan koreksi terhadap penyebaran informasi atau rumor yang berpotensi menimbulkan ketegangan antar kelompok sosial; Kedua, bekerjanya lembaga penyelesaian masalah, baik yang bersifat formal seperti pengadilan atau informal seperti lembaga adat dan agama; Ketiga, adanya tokoh-tokoh pro perdamaian yang memiliki pengaruh, sumberdaya dan strategi efektif dalam mencegah mobilisasi masa oleh tokoh pro-konflik; Keempat, struktur sosialpolitik yang mendukung terwujudnya keadilan dalam masyarakat; dan Kelima, struktur sosial-politik yang adil bagi bertahannya integrasi sosial. ${ }^{23}$

Oleh karena itu, sebagai seorang pendidik, guru harus mampu mengurai perbedaan ras, bahasa, warna kulit dalam mengimplentasikan moderasi beragama di sekolah. Sehingga peserta didik dapat mengambil contoh atas tindakan yang dilakukan oleh guru itu sediri dalam implementasi nya dalam kehidupan nyata.

${ }^{22}$ Fauzi, Ahmad. "Moderasi Islam, Untuk Peradaban Dan Kemanusiaan." Jurnal Islam Nusantara 2.2 (2018), hlm, 235.

${ }^{23}$ Kementerian Agama, R. I. "Moderasi Beragama." Jakarta: Badan Litbang dan Diklat Kemenag RI (2019), Hlm. 58. 


\section{Implementasi Moderasi beragama dalam proses belajar mengajar.}

Belajar mengajar tidak bisa dilepaskan dalam dunia pendidikan karena belajar mengajar merupakan dua intraksi yang saling ketergantungan, dimana ada proses belajar tuntu pula ada proses mengajar atau pengajaran. Menurut Habernas, belajar baru akan terjadi jika ada interaksi antara individu dengan lingkungannya. Ia membagi tipe belajar menjadi tiga, yaitu: (a) belajar teknis (technical learning) yaitu belajar bagaimana seseorang dapat berinteraksi dengan lingkungan alamnya secara benar; (b) belajar praktis (practical learning) yaitu belajar bagaimana seseorang dapat berinteraksi dengan lingkungan sosialnya, yaitu dengan orang-orang di sekelilingnya dengan baik; (c) belajar emansipatoris (emancipatory learning) Yaitu belajar yang menekankan upaya agar seseorang mencapai suatu pemahaman dan kesadaran tinggi akan terjadinya perubahan atau transformasi budaya dengan lingkungan sosialnya. ${ }^{24}$

Guru, sebagai seorang pendidik bertugas menyalurkan, mengarahkan dan memotivasi peserta didik agar dapat mengembangkan potensi yang dimilikinya, bukan mendikti, memaksa kehendak, apalagi mengekang kebebasan peserta didik untuk berkreasi.Setiap peserta didik memiliki potensi yang berbeda-beda. Keunikan itu harus dimanfaatkan oleh guru untuk menjadikan potensi-potensi yang dimiliki peserta didik dapat mengembangkan peserta didik dalam menghargai dan menghormati orang lain.

Dalam proses pengajaran dan pembelajaran, peserta didik akan berfikir terbuka, yaitu berfikir bagaimana dapat menghargai hak hidup, hak berpendidikan, hal untuk berekpresi, hak untuk memeluk agama dan tidak mudah menyalahkan orang lain. Sebagai akibat dari perjumpaan dengan dunia lain, agama, dan kebudayaan-kebudayaan yang beragam akanmengarahkan peserta didik untuk berfikir lebih dewasa dan memiliki sudut pandang dan cara memahami realitas dengan berbagai macam cara. ${ }^{25}$

Sebagai generasi penerus bangsa, tentunya harus diberikan pemahaman yang luas tentang bagaimana menerepkan islam yang rohmatanlilalamin dan menjadikan islam sebagai landasan bergaul dengan orang lain dengan menghargai perbedaan. Hal ini membutuhkan ketelatenan guru dalam menanamkan moderasi beragama. Implentasi moderasi beragama dalam proses belajar mengajar dapat diterapkan dalam metode pembelajaran sebagai berikut:

1) Metode diskusi

Diskusi dalam Kamus Besar Bahasa Indonesia adalah pertemuan ilmiah untuk bertukar pikiran mengenai suatu masalah. ${ }^{26}$ Diskusi merupakan

\footnotetext{
${ }^{24}$ Teori-belajar-humanistik. diakses pada24-01-20.

25 Zakiyuddin Baidhawy, hlm. 83.

${ }^{26}$ Kamus besar bahasa Indonesia online. Diakses pada tanggal 24-01-20
} 
sebuah interaksi komunikasi antara dua orang atau lebih/kelompok. Biasanya komunikasi antara mereka atau kelompok tersebut berupa salah satu ilmu atau pengetahuan dasar yang akhirnya akan memberikan rasa pemahaman yang baik dan benar. ${ }^{27}$ Dengan demikian, dapat simpulkan bahwa diskusi merupakan interasi antara dua orang atau lebih untuk membicarakan problem atau masalah tertentu dengan tujuan tertentu yang diingikan.

Metode diskusi memberikan banyak manfaat bagi peserta didik dalam proses belajar mengajar yaitu melatih peseta didik berpikir kritis dan terbuka sehingga setiap peserta didik memiliki wawasan yang luas yang bersumber dari peserta didik lainnya. Kemudian dengan berdiskusi peserta didik memiliki sifat demokratis karena dapat mengutarakan pendapat masih di forum diskusi. Kemudian dengan berdiskusi, peserta didik memiliki sikap saling menghargai pendapat orang lain yang berbeda-beda. Kemudian, dengan berdiskusi, peserta didik dapat menambah pengetahuan dan pengalaman yang bersumber dari hasil diskusi. Dengan berdiskusi, kemanpuan berfikir peserta didik dapat terasah, berfikir kritis, kreatif dan argumentative, dan melatih mental peserta didik dalam mengemukakan pendapat di depan umum. ${ }^{28}$

Proses belajar mengajar dengan menerapakan metode diskusi memberikan keleluasaan bagi peserta didik untuk mengekpresikan pengetahuan dari masing-masing peserta didik. Dengan berdiskusi, peserta didik dapat mengenal karakter masing-masing bagaimana menyikapi dan mengekpresikan sebuah problem dengan tema yang telah ditentukan.

2) Kerja kelompok

Islam mengajarkan pengikutnya untuk saling tolong menolong dalam kebaikan sebagaimana dijelaskan dalam Al-Qur'an surat al-Maidah ayat 2.

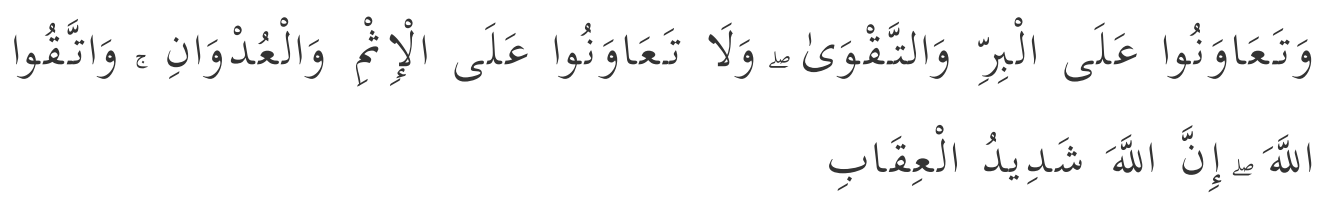

“..dan tolong-menolonglah kamu dalam (mengerjakan) kebajikan dan takwa, dan jangan tolong-menolong dalam berbuat dosa dan pelanggaran. dan bertakwalah kamu kepada Allah, Sesungguhnya Allah Amat berat siksa-Nya. (Al-Maidah ayat 2)"

\footnotetext{
${ }^{27} \mathrm{https} / / /$ id.wikipedia.org/wiki/Diskusi, diakses pada tangal 24-01-20

28 https://jagad.id/pengertian-diskusi-macam-jenis-fungsi-manfaat-dan-tujuan/diakses pada tanggal 25-01-20
} 
kata al-birru memiliki arti kebaikan. Mengerjakan kebaikan tanpa melihat status sosial, agama, dan kepercayaan seseorang. Karena kebaikan merupakan kebutuhan seluruh umat manusia.

Kerja kelompok merupakan kegiatan saling tolong menolong dalam pembelajaran. Peserta didik diharuskan untuk saling kerja sama dalam melaksanakan tugas-tugas yang diberikan kepada peserta didik. Saling membantu dalam menyelesaikan soal-soal yang diberikan guru.

Kerja kelompak dalam pengertiannya adalah penyajian materi dengan cara pemberian tugas-tugas kepada peserta didik yang sudah dikelompokkan untuk mencapai tujuan. ${ }^{29}$ Esensi dari kerja kelompok adalah untuk gotong royong, saling membantu dalam menyelesaikan sebuah permasalah dalam pembelajaran. ${ }^{30}$

Bagi seorang pendidik, metode kerja kelompok penting untuk diterapkan karena melatih peserta didik untuk saling memahami arti kebersamaan. Selain itu kerja kelompok memiliki banyak manfaat sebagaimana digambarkan oleh Zakiah Darajdat yaitu membina kerja sama antar peserta didik yang satu dengan peserta didik lainnya, memperoleh penguasaan atas bahan pengajaran, memupuk dan memelihara rasa persatuan dan kesatuan dalam suatu kelompok, melatih kepemimpinan peserta didik, mengembangkan rasa setia kawan dan sikap tolong menolong, memberikan kesempatan kepada peserta didik untuk mengaktualisasi diri dalam merencanakan sesuatu demi kepentingan bersama, mengarahkan pertumbuhan dan perkembangan pribadi peserta didik dalam kehidupan bermasyarakat. ${ }^{31}$

Oleh sebab itu, metode kerja kelompok ini bagian dari strategi guru dalam menanamkan moderasi beragama bagi peserta didik sehingga peserta didik bersifat lowes dan tidak esklusif dalam beragama.

3) Metode Study Tour (Karya Wisata)

Memberikan pengalaman langsung kepada peserta didik tentang moderasi beragama merupakan bagian dari salah satu cara agar peserta didik dapat mengamalkan pengetahuan yang didapat di dalam kelas kemudian di implementasikan dalam kehidupan nyata. Salah satu metode yang digunakan adalah karya wisata (Study Tour). Metode karya wisata ini didefinisikan sebagai metode pembelajaran yang berada diluar kelas, mengunjungi tempat-tempat yang dituju di luar kelas agar dapat

\footnotetext{
${ }^{29}$ Ramayulis, Metodologi Pengajaran Islam, (Jakarta: Kalam Mulia, 1994)hlm. 179

${ }^{30}$ Imansjah Alpandie, Didaktik Metodik, (Surabaya: Usaha Nasiona, 1984), hlm. 93.

${ }^{31}$ Zakiah Darajat, Metodologi Pengajaran Agama Islam, (Jakarta: Bumi Aksara, 2008), hlm 159160.
} 
pembelajaran langsung dari objek yang dituju. Ariyanto mendefinisikan metode karya wisata sebagaimetode pengajaran yang dilaksanakan diluar kelas dengan cara mengajak peserta didik memperhatikan keadaan lingkungan atau peristiwa yang ada hubungannya dengan bahan pembelajaran yang sedang dibahas atau menunjukkan langsung kepada objek tertentu. 32 Keterlibatan peserta didik secara langsung dapat membantu peserta didik mengembangkan diri, merespon, mengapresiasi, dan mengaktualisasi pengetahuan peserta didik yang didapat didalam kelas, kemudian diasosiasikan dalam lingkungan sekitar. ${ }^{33}$

Metode karya wisata ini memiliki beberapa manfaat antara lain: Peserta didik dapat belajar secara langsung terhadap objek yang dikunjungi, peserta didik dapat memperoleh pemantapan teori-teori di pelajari di sekolah dengan kenyataan aplikasi yang diterapkan pada objek yang dikunjungi,peserta didik dapat menghayati pengalaman praktek suatu ilmu yang telah diperolehnya, peserta didik dapat memperoleh informasi yang lebih akurat dengan jalan melakukan wawancara atau dengan mendengarkan ceramah yang diberikan oleh petugas setempat, dapat mempelajari beberapa materi pelajaran sekaligus dan integral. ${ }^{34}$

Penggunaan metode karya wisata dalam pembelajaran moderasi beragama merupakan bagian dari usaha pendidik agar dapat memberikan pengalaman hidup dengan orang yang lain yang berbeda-beda baik dari kultur, budaya, kepercayaan, dan status sosial. Karena moderasi beragama perlu dipraktikan dalam kehidupan peserta didik. Tentunya, guru harus mengarahkan, membimbing, dan menunjukkan kepada peserta didik tentang pentingnya moderasi beragama saat mengadakan kunjungan ke tempat-tempat yang telah ditentukan sesuai dengan materi pembelajaran yang dijelaskan di dalam kelas.

Oleh karena itu, guru harus dapat memilah dan memilih metode yang tepat bagi peserta didik agar pemahaman konsep moderasi beragama dapat melekat dalam diri peserta didik kemudian dapat diimplentasikan kehidupan berbangsa dan bernegara.

\footnotetext{
${ }^{32}$ BambangAriyanto. "Peningkatan Perilaku Islami Anak Usia Dini Melalui Metode karyawisata." Jurnal Pendidikan Usia Dini 8.2 (2014): hlm, 230.

${ }^{33}$ Claudia Eliason, dkk., "A Pratical Guide To Early Childhood Curriculum, Eighth Edition" (Columbus, Ohio: Pearson Merrill Prentice Hall, 2008), hlm. 287.

${ }^{34}$ Bambang Ariyanto. "Peningkatan Perilaku Islami Anak Usia Dini Melalui Metode karyawisata." Jurnal Pendidikan Usia Dini 8.2 (2014): hlm, 231.
} 


\section{Penutup}

Dari beberapa pemaparan diatas dapat diambil kesimpulan bahwaperan Guru Agama dalam menanamkan Moderasi begarama di lembaga pendidikan sangat penting karena guru memilik peran penting untuk memberikan pemahaman dan pengertian yang luas tentang islam yang rohmatan lil alamin yang dapat menghargai perbedaan. Moderasi beragama bagian dari usaha bersama agar bangsa indonesia ini terhindar dari perpecahan karena perpecahan merupakan awal dari kehancuran sebuah bangsa. Selanjutnya, Implementasi moderasi beragama proses belajar mengajar dapat dilakukan dengan menggunakan metode diskusi, kerja kelompak, dan karya wisata. Dengan ketiga metode tersebut guru dapat dengan mudah memberikan pengertian keberagaman, menghargai orang lain, menghargai pendapat orang lain, dan toleran. selain mendidik dan memberikan pemahaman kepada peserta didik betapa pentingnya hidup saling mengasihi dan menghargai hak untuk hidup, hak untuk beribadah sesuai dengan kayakinan masing-masing. 


\section{DAFTAR PUSTAKA}

\section{Buku}

Baidhawy, Zakiyuddin. Pendidikan Agama Berwawasan Multikultural, Jakarta: Earlangga, 2005.

H.A.R. Tilaar. Multikulturalisme Tantangan Global Masa Depan dalam Transformasi Pendidikan Nasional, Jakarta: Grasindo, 2003.

Iyubenu, Edi Ah. Hate Speech' dalam Kecamata Islam, Kedaulatan Rakyat, 13 November 2015, hlm. 12.

Majid, Nurkholis. Pluralitas Agama: Kerukunan dalam Kergaman, Jakarta: Kompas Nusantra, 2001.

Uno,Hamzah B. Profesi Kependidikan, Problema, Solusi, dan Reformasi Pendidikan di Indonesia,Jakarta: Bumi Aksara, 2007.

Kementerian Agama, R. I. "Moderasi Beragama." Jakarta: Badan Litbang dan Diklat Kemenag RI, 2019.

Fatoni,Muhammad Sulton. Buku Pintar Islam Nusantra, Tanggeran Selatan: IIMaN, 2017.

Ramayulis. Metodologi Pengajaran Islam, Jakarta: Kalam Mulia, 1994.

Alpandie, Imansjah. Didaktik Metodik, Surabaya: Usaha Nasiona, 1984.

Darajat, Zakiah. Metodologi Pengajaran Agama Islam, Jakarta: Bumi Aksara, 2008.

Eliason, Claudia, dkk., "A Pratical Guide To Early Childhood Curriculum, Eighth Edition" Columbus, Ohio: Pearson Merrill Prentice Hall, 2008.

Yakin,Ainul, Pendidikan Multikultural; Cross-Culture Understanding untuk Demokrasi dan Keadilan, Yogyakarta: Pilar Media, 2005.

Zamroni, Pendidikan Demokrasi pada Masyarakat Multikultural, Yogyakarta: Gavin Kalam Utama, 2011

Biyanto, Urgensi Plurarisme, Kedaulatan Rakyat, 13 November 2015, hlm. 12.

UU Republik Indonesia Nomor 20 Tahun 2003 tentang Sistem Pendidikan Nasiona, Jakarta: Lembaran Negara, 2003.

Tribujogja, Senin, 16 November 2015, hlm, 1 
Undang-undang Pemerintah nomor 2 tahun 1989.

\section{Jurnal}

Al Arifin, Akhmad Hidayatullah, Implementasi Pendidikan Multikultural Dalam Praksis Pendidikan di Indonesia, Jurnal Pembangunan Pendidikan: Fondasi dan Aplikasi, UNY, Volume.1 Nomor 1 juni tahun 2012.

Ariyanto, Bambang "Peningkatan Perilaku Islami Anak Usia Dini Melalui Metode karyawisata." Jurnal Pendidikan Usia Dini 8.2 (2014).

Fauzi, Ahmad. "Moderasi Islam, Untuk Peradaban Dan Kemanusiaan." Jurnal Islam Nusantara 2.2 (2018)

Akhmadi, Agus. "Moderasi Beragama Dalam Keragaman Indonesia." Inovasi 13.2 (2019)

\section{Internet}

https://sites.google.com/site/mulyanabanten/home/teori-belajarbehavioristik/teori-belajar-kognitif/teori-belajar-konstruktivistik/teoribelajar-humanistik. .

https://id.wikipedia.org/wiki/Diskusi, https://jagad.id/pengertian-diskusi-macam-jenis-fungsi-manfaat-dan-tujuan/ Tarmidzi Tohor, $\quad$ https://bimasislam.kemenag.go.id/post/opini/pentingnyamoderasi-beragama

https://tafsirweb.com/598-surat-al-baqarah-ayat-143.html.

Kamus besar bahasa Indonesia online. 